\title{
MARKET STRUCTURE EFFECTS ON WAGES IN THE BRAZILIAN INDUSTRIAL FIRMS
}

\author{
GILSON GERALDINO SILVA-JR* \\ Catholic University of Brasilia
}

Submitted August 2010; accepted March 2011

\begin{abstract}
In this paper we analyze market structure effects on wage in the Brazilian manufacturing sector between 1998 and 2005. Our comprehensive linked employer-employee data has observation at firm and worker data level, as market share, wages and skills. We also control potential endogeneity through a quasi-natural experiment. There are few empirical studies analyzing market structure effects on wages at firm level. As far we know it is the first study in this subject for Brazilian Industrial firms.
\end{abstract}

JEL classification codes: J31, C23

Keywords: wages, skills, market structure, Brazilian manufacturing

\section{Resumo}

Neste artigo analisamos os efeitos da estrutura de mercado sobre os salários na indústria brasileira de transformação entre 1988 e 2008. A ampla base de dados, com informações conectáveis empregado-empregador, tem observações por firma e por trabalhador. Entre elas, estrutura de mercado, salários e qualificação. Controlamos potencial endogeneidade através de experimento quase natural. Há poucos estudos analisando os efeitos da estrutura de mercado sobre salários por firma. Até onde sabemos, este é o primeiro estudo desta natureza para firmas brasileiras da indústria de transformação.

\section{Palavras-Chave}

salários, qualificação, estrutura de mercado, indústria brasileira de transformação

\footnotetext{
* Graduate Programme in Economics Catholic University of Brasília SGAN 916 - CEP 70790-160 Brasília - DF E-mail: gilson@ucb.br

I thank to CNPq for financial support; IBG for datas accsess; and João de Negri, Danilo Coelho, Eduardo Ribeiro, Marcelo Portugal and three anonymous referees for their comments and suggestions. Any mistake is my responsibility.
} 


\section{Introduction}

While the most common labor market models assume competitive product markets, non-competitive markets seem to be the norm in output markets (Nickel, 1999). Wage differentials between firms also suggest that a unique wage rate for all firms is not a good description of the labor market (Abowd et al., 1999). There are a number of models that relate market power, in the form of excess profits, with wages, such as profit sharing and union bargaining (Brown and Medoff, 1989). Under imperfect substitution of worker types, firms with higher profits (reflecting market power) have incentives to attract more skilled workers as a cost saving device, increasing skill returns. But product market high market share may generate monopsony labor market structure, with firms internalizing productivity differentials (Autor, Levy and Murnane, 2006).

There are few works that try to use matched employer-employee data to study competition effects on wages, particularly for Brazil. Menezes-Filho, Muendler and Reamey (2008) match workers and employers for a particular state in Brazil (São Paulo) using the same worker data set as we do, to analyze the structure of worker compensation in Brazil, with a comparison to France and the United States. Martins and Esteves (2006) use the same underlying data set we use, evaluating and rejecting profit sharing for Brazilian manufacturing but do not evaluate the effect of market structure on wages.

In brief, there are several studies about wage differentials and matched worker and firm data, but not about the relationship between wages and market structure. There are a few but an important empirical literature about market structure and wages (e.g., Long and Link, 1983), but using sectorial data. And there are few studies analyzing market structure effects on wages at firm and worker level. In this paper, we analyze market structure effects on wage in the Brazilian manufacturing sector between 1998 and 2005. Our larger sample has observation at firm and worker data level, as market share, wages and skills. As far we know it is the first study in this subject for Brazilian Industrial firms.

We also control potential endogeneity through a quasi-natural experiment - better than instrumental variables, according to an important applied econometric literature. An exogenous source of market power variation (as the sharp exchange rate variation in 2002-2003) is a way of correcting the potential simultaneity between wages and market share. This exchange rate change was induced by political risk from a presidential election, with the exchange rate doubling within a year. Advancing the results, which, as far as we know, have not been found for Brazil and are some the few at firm and worker 
level in the literature, we highlight that: 1) higher-skilled workers earns high and 2) the skill premium is accentuated by market share. Considering that the market share is also a way to measure firm size, ${ }^{1}$ this result also suggests that bigger Brazilian manufacturing firms pay highly skilled workers better wages than do smaller firms. After this introduction, we review the literature on this topic, explain our empirical specification, present the results and interpretations, and draw our conclusions.

\section{Related Literature}

Wages differ in the market according to worker and firm characteristics. There seems to be high-wage workers and high-wage firms. A high-wage worker is someone who earns a greater gross income than is expected, considering observable characteristics such as experience, education, religion or gender. A firm that pays high wages is an employer that remunerates above mean wages, given the same observable characteristics of the worker (high-wage firm) (Abowd, Kramarz and Margolis, 1999).

An important firm characteristic that may influence the high wage firms is market structure positioning and its market power. Theoretical investigations suggest a negative impact of monopolistic power on the labor market, much like a monopolist is able to capture consumer surplus. There is strong evidence that the division of monopoly revenues and high wages are positively correlated with market power. Nevertheless, it is not clear whether it happens due to the actions of unions, or whether this pattern also occurs in non unionized sectors (or with poorly active unions). However, the mechanisms whereby competition in the product market impacts the labor market are clearer: the managers' and workers' effort and the decisions related to technological innovation (Nickel, 1999).

Databases with linked employer-employee information permit substantial improvements in the analyses of labor market, as shown by the literature on the topic. Significant economic changes in the last 30 years, such as changes in international business patterns, technological development and work restructuring, have irreversibly impacted labor, increasing the relevance of this kind of information. The full understanding of the impacts of these changes on income inequality, on employment and earnings depends on information that permits linking employees and employers (Haltiwanger et alli, 1998).

\footnotetext{
${ }^{1}$ Market share means is an old discussion. Here we consider two possible interpretations: market power and firm size. More details about it see Caves and Porter (1978) and Schmalensee (1989).
} 
A review of about 100 studies for 15 countries conducted in the late 1990s confirms that the analysis of labor market based on data that connect information about employees and employers allows obtaining more precise estimates of the relation between wage and employment, as well as detecting their determinants (Abowd and Kramarz, 1999a). Among the advantages of econometric analysis, control for potentially endogenous fixed effects, and reduction of heterogeneity bias, which occur when information about specific firm or workers' characteristics are absent from the database (Abowd and Kramarz, 1999b). We follow this literature.

In fact, until recently, the empirical analyses involving heterogeneous earnings and firms were based on inappropriate databases to separately identify the individual effects necessary to classify a worker or firm as high-wage. Using a French database linking workers' and employers' information and controlling for observable and unobservable heterogeneity, Abowd, Kramarz and Margolis (1999) decomposed the total real annual income per worker into observable characteristics of the employer, and heterogeneity of individuals and firms. While the larger share of industry wage differentials and firm size effects are explained by worker effects, firm effects are significant. High-wage workers are the most productive but not the most profitable. Firms using high wage workers are also more capital-intensive, less likely to survive, and they are not the most intensive in highly qualified work (Abowd, Kramarz and Margolis, 1999).

The effects of exchange rate shocks and competitive pressure on the labor market are significant since exchange rate fluctuation alters the relative prices of inputs and outputs. Competitive pressure induces firms to change their market strategies, and technological change modifies the demand for labor force.

A recent study on the effect of competition, namely, foreign competition on wages is Guadalupe (2007) for British manufacturing. Empirical evidence, which was obtained through the use of a quasi-natural experiments ${ }^{2}$ (pound devaluation in 1996 particularly) suggests that the skill returns in a given industry increase with competition; and exchange rate fluctuation increase skill returns not only for workers with intermediate educational level, but also for highly qualified ones. It should be underscored, at least, that union power is not important to set up wages in the Brazilian manufacturing sectors (Lima and Resende, 2003), and there is no evidence in favor of rent sharing in those sectors as well (Martins and Steves, 2006).

\footnotetext{
${ }^{2}$ Alatas and Cameron (2008) recently also use quasi-natural experiment, but to analyze the impact of minimum wages on employment in Indonesia.
} 


\section{Empirical Specification}

In order to capture the relationship between wages and market structure, considering firm product market power and labor force skills, we estimate earnings models on unbalanced panels using fixed effects of firms and workers, and their interactions. Our base specification is as follows:

$w_{i k j t}=\beta_{0}+\beta X_{i k j t}+\Psi_{i}+\Phi_{J(i, t)}+\Gamma_{i j}+\varepsilon_{i k j t}$

where $w_{\text {ikjt }}$ is the workers $\mathrm{i}=1, \ldots, \mathrm{N}$ wage with educational level $\mathrm{k}=1, \ldots, 3$ in firm $\mathrm{j}=1, . ., \mathrm{J}$ at $\mathrm{t}=1, \ldots, T ; X_{\mathrm{ikjt}}$ is the matrix of (traditionally) observable characteristics of workers and firms; $\beta_{0}$ is the intercept of the regression equation; $\beta$ is the coefficient vector associated with workers' and firm characteristics over time; $\Psi_{\mathrm{i}}$ is the vector of fixed effects of worker i; $\Phi_{J(\mathrm{i}, \mathrm{t})}$ is the vector of fixed effects for firms $j$ in which $i$ workers were hired at $\mathrm{t}$; $\Gamma_{i j}$ represents the interaction between $\Psi_{i}$ and $\Phi_{\mathrm{J}(\mathrm{i}, \mathrm{t})}$, i.e, $\Gamma_{\mathrm{ij}}=\Psi_{\mathrm{i}}^{*} \Phi_{\mathrm{J}(\mathrm{i}, \mathrm{t})}$; and $\varepsilon_{\mathrm{ikjt}}$ is the error term.

This specification interact skill levels with firm characteristics. The linear specification for skills minimizes measurement error on the skill level and allowing for the strong diploma effects ${ }^{3}$ in Brazil. We interact firm and worker fixed effects to accommodate firm specific knowledge.

In countries like Brazil with low average skill levels, and little or no apprentice schooling, worker technical skills are often provided by the firm. Brazilian Industrial Confederation (CNI, Confederação Nacional da Indústria) keeps a continuous worker training system (SENAI, Serviço Nacional de Aprendizagem Industrial). It provides industrial worker skills upgrade, which change over time. It should be remarked because firm specific skills by worker are important to any theory of worker-firm wage differentiation. In addition, we exploit exogenous variation in competitive pressure arising from relative price changes in the form of the 2002 sharp devaluation, interacted with firm characteristics. This type of analysis allow for heterogeneous responses by firm types to exchange rate changes. Given the possible interaction between high-wage workers and high-wage firms, a firm could have bigger market share just because it decided to spend more on its workers. It hired the most productive workers and this productivity was turned into more competitiveness (lower costs, better products, etc), allowing the firm to gain market share. The fixed effects capture this possibility.

\footnotetext{
${ }^{3}$ Diploma effects mean degree impact on wages. For example, a high school worker that gets an undergraduate degree has a diploma effect on his wage. However, sometimes is not clear if wage premium is due to skills or more formal school years. Our regression controls it as we consider not only school levels but also age and tenure.
} 
We could have endogeneity problem because market share can be determined simultaneously with wages, or be correlated with some omitted variable, such as technological change. As firms hire highly qualified workers, larger productivity associated with these workers help them gain market share; or as they gain market share, they need to hire more workers to keep their relative position, whose demand impacts on average wages. Before we go ahead, let's review the debate between two possible endogeneity solutions: instrumental variable and quasi-natural experiments.

\section{A. Instrumental Variable versus Quasi-Natural Experiments}

Instrumental variables (IV) are a traditional and widely used possible solution to endogeneity. This approach essentially assumes that some components of nonexperimental data are random. That is, it is assumed that some variable or event satisfies the criterion of "randomness"- the event or variable is orthogonal to the unobservable and unallowable factors that could affect the outcomes under study. However, IV has many weaknesses. For example, Buse (1992) gives the specific conditions to the potential bias of instrumental variable estimators, i.e., augmenting the set of instrumental variables will may increase the bias of the estimator and might also conclude that there is necessarily a trade-off between bias and efficiency.

Bound, Jaeger, Baker (1995) point out problems with instrumental variables estimation when the correlation between the instruments and the endogenous explanatory variable is weak. They draw attention to two problems associated with the use of IV. First, the use of instruments that explain little of the variation in the endogenous explanatory variables can lead to large inconsistencies in the IV estimates even if only a weak relationship exists between the instruments and the error in the structural equation. Second, in finite samples, IV estimates are biased in the same direction as Ordinary Least Squares (OLS) estimates. In sum, their results illustrate that the use of instruments that jointly explain little of the variation in the endogenous variable can do more harm than good.

Angrist and Krueger (2001) agree with Buse (1992) and Bound, Jaeger, Baker (1995). The most important potential problem is a weak instrument, that is, an instrument that is correlated with the omitted variables (or the error term in the structural equation of interest in the case of simultaneous equations). Another concern is the possibility of bias when instruments are only weakly correlated with the endogenous regressor(s).

In fact, instrumental variables estimates with very weak instruments tend to be centered on the corresponding ordinary least squares estimate. An additional difficulty is inter- 
preting instrumental variables estimates. Not every observation's behavior is affected by the instrument, so instrumental variables methods can be thought of as operating by using only part of the variation in an explanatory variable - that is, by changing the behavior of only some people. In other words, instrumental variables provide an estimate for a specific group-namely, people whose behavior can be manipulated by the instrument. Given the lack of credibility of many of the assumptions of standard instrumental variable studies, economists as well as researchers in other fields have sought out "natural experiments," random treatments that have arisen as an important option.

The advantage of the quasi-natural experiments (QNE) approach is that the assumption of randomness for the instrumental variable (IV) employed is more credible than for those instruments used in almost all other studies (Rosenzweig and Wolpin, 2000). In sum, applied econometric literature offers a second option to endogeneity problem: quasi-natural experiments. The use of QNE to evaluate treatment effects in the absence of truly experimental data has gained wide acceptance in empirical research in economics and other social sciences. Many researchers consider QNE better than IV as endogeneity solution nowadays. There are a larger literature about it and many applications, as Meyer (1995) and Rosenzweig and Wolpin (2000) surveys points out. ${ }^{4}$

We exploit exogenous variation in covariates from quasi-natural experiments. A quasinatural experiment, such as exchange rate overshooting for 2002-2003, ${ }^{5}$ creates exogenous variation in explanatory firm variables that compensates for potential endogeneity, as different sectors were simultaneously affected in different time periods, exogenously altering intra-sectorial competition. Our exogenous variation in competitive pressures comes from exchange rate variation due to political risk in 2002 in Brazil. In this case, the ordinary least squares estimates are equivalent to difference-in-differences estimates (Cameron and Trivedi, 2005).

The difference-in-differences (DID) estimator is one of the most popular tools for applied research in economics to evaluate the effects of public interventions and other treatments of interest on some relevant outcome variables. DID estimator is based on an simple idea: simple comparisons of pre-treatment and post-treatment outcomes for individuals exposed to a treatment are likely to be contaminated by temporal trends in the outcome variable or by the effect of events, other than the treatment, that occurred between both periods. However, when only a fraction of the population is exposed to the treatment, an untreated comparison group can be used to identify temporal varia-

\footnotetext{
${ }^{4}$ Bertrand, Duflo and Mullainathan (2004) remark potential standard errors inconsistency if DID is applied in presence of serial correlation. They also remark that computing standard errors that are robust to serial correlation appears relatively easy to implement in most cases. Nowadays it is available in any standard econometric package. We consider it in our estimations.

${ }^{5}$ Law change is another popular source of exogeneity in QNE context. Besley and Case (2000) analyses when it is reasonable to treat differences in state laws as "natural experiments".
} 
tion in the outcome that is not due to treatment exposure. ${ }^{6}$ Now we can present our econometric specification.

\section{B. Econometric Specification}

Our regression is as follows:

$$
\begin{aligned}
& l n w_{i k j t}=\alpha_{0}+\alpha_{1} T E N_{i j t}+\alpha_{2} A G E_{i t}+\alpha_{3} D M_{i t}+\alpha_{4} D H_{i t}+\alpha_{5} D 02_{t}+\alpha_{6} D 02 D M_{i t} \\
& +\alpha_{7} D 02 D H_{i t}+\alpha_{8} M S_{j t}+\alpha_{9} M S_{j t} D 02+\alpha_{10} M S_{j t} D M_{i t}+\alpha_{11} M S_{j t} D H_{i t}+\alpha_{12} M S_{j t} D 02 D M_{i t} \\
& +\alpha_{13} M S_{j t} D 02 D H_{i t}+\Psi_{i}+\Phi_{J(i, t)}+\Gamma_{i j}+\varepsilon_{i k j t}
\end{aligned}
$$

Where $\ln _{\mathrm{ikjt}}$ is the (natural) log wage of worker wage. TEN $\mathrm{N}_{\mathrm{ijt}}$ (tenure) is the number of months worker i worked at firm $\mathrm{j}$ up to $\mathrm{t} ; \mathrm{AGE}_{\mathrm{it}}$ is the age of worker $\mathrm{i}$ at $\mathrm{t} ; \mathrm{DM}_{\mathrm{it}}$ and $\mathrm{DH}_{\mathrm{it}}$ are dummies that indicate intermediate or high educational level, respectively, for worker $i$ at t. Low educational level is the omitted category. Altogether, years of tenure, age and educational level sum up skills and capture the impact of observable worker's characteristics on wages.

$\mathrm{MS}_{\mathrm{jt}}$ is the market share of firm $\mathrm{j}$ at $\mathrm{t}$, or the revenue of firm $\mathrm{i}$ in relation to the revenue of all firms in the sector in which it operates; $\mathrm{MS}_{\mathrm{jt}} \mathrm{DM}_{\mathrm{it}}$ and $\mathrm{MS}_{\mathrm{jt}} \mathrm{DH}_{\mathrm{it}}$ are the interactions between the firm market share and the skill dummies.

D02 is the dummy for year 2002 (D02=1 for 2002 and zero otherwise) which captures the impact of exchange rate fluctuation on wages; $\mathrm{D} 02 \mathrm{DM}_{\mathrm{it}}$ and $\mathrm{D} 02 \mathrm{DH}_{\mathrm{it}}$ are the interactions between the dummy for 2002 and the intermediate and high educational level of worker $i$ at $t$, respectively (which capture the effects of exchange rate fluctuation per educational level).

$\mathrm{MS}_{\mathrm{jt}} \mathrm{D} 02$ is the interaction of market share of firm $\mathrm{j}$ at $\mathrm{t}$ with the dummy for 2002 (which captures the effect of exchange rate fluctuation on market share), and $\mathrm{MS}_{\mathrm{jt}} \mathrm{D} 02 \mathrm{DM}_{\mathrm{it}}$ and $\mathrm{MS}_{\mathrm{jt}} \mathrm{D} 02 \mathrm{DH}_{\mathrm{it}}$ are the interactions of $\mathrm{MS}_{\mathrm{jt}} \mathrm{D} 02$ with some intermediate and high educational levels (which capture the effects of exchange rate fluctuation on market share in each educational level).

In sum, this specification includes quasi-natural experiments (exchange rate overshooting) as alternative solution to endogeneity, has the aim to capture the effect of market share on wages, considering the qualification of workers in the Brazilian industrial

\footnotetext{
${ }^{6}$ For technical details, intuition, formalism and many examples about QNE and DID, please check Durlauf and Blume (2010), Angrist and Pischke (2009) and Cameron and Trivedi (2005).
} 
firms. As Cameron and Trivedi (2006) remark, natural or quasi-natural experiments naturally create treatment and control groups; and the main advantage of using data from a natural experiment is that a policy variable of interest might be validly treated as exogenous. In our case, not all firms were affected by Real devaluation, especially in the same amount. So we have a treated and non treated group: intensive affected (treated) and not affected (non treated) by Real devaluation. ${ }^{7}$

As a matter of fact, to verify whether higher competition in the product market alters wages due to workers' qualification, it is necessary to consider not only the exogenous source of variation in the competition level in the product market (captured by the dummy for 2002 and interactions), but also unobservable heterogeneity and changes over time in sectoral composition and worker education change (through tradition school or SENAI courses). It is captured by the fixed effects of firms and workers. Implicitly, in the equation the econometrics is equivalent to a transformation that contains a differentiating over time, i.e., we suggest an estimation of a linear panel data model with fixed effect that is, in practice, a more complex form of a difference-in-difference estimator. In fact, due to fixed effects, this is really difference-in-difference-in-difference approach, as we compare changes over time before 2002 with changes over time after 2002.

Someone could say that with fixed effects we can't identify the effects of time-constant variables; and that education change is associated with measurement error. But it is not true because industrial workers education in Brazilian industry is not constant. Industrial training system (SENAI) is available throughout the Country and provides continuous training to Brazilian industrial workers. In spite of formal education level change be hard and Brazilian workers normally do not back to traditional school system, effective industrial educations is provided and full accessible for industrial workers, specially to low and medium educational level. And high level workers attend to manage education (as MBA's) time to time. So, there is effective change in education in the Brazilian industrial labor force and it can't be consider measurement error.

In summary, with this regression is possible to capture the impacts of competition on average wages (conditional to skills) in the Brazilian industrial firms.

\section{Data Base and Variables}

Our data base are the Industrial Annual Survey (Pesquisa Industrial Anual, PIA) produced by Brazilian Census Office (Instituto Brasileiro de Geografia e Estatistica, IBGE)

\footnotetext{
${ }^{7}$ We are not able to build detailed descriptive statics to illustrate treated and non treated firms because of census confidentiality.
} 
and Labor Annual Survey (Relação Annual de Informação Sociais, RAIS) produced by Ministry of Labor. PIA is a firm level industrial annual survey to Brazilian manufacturing. It began in 1966 and changed completely in 1996 to be according to modern survey technology. It has been drawn according to concentration industrial. All industrial firms with more than 30 employees are in this survey. As smaller firms are the majority in number but the minority in economic activity, PIA has a sample to industrial firms with more than 5 and less than 30 employees. PIA allow us calculate at firm level market share as $\mathrm{MS}_{\mathrm{it}}=$ firm $\mathrm{i}$ at year $\mathrm{t}$ revenue/sector revenue at year $\mathrm{t}$, where sector is SIC 4 digit disaggregation level. ${ }^{8}$

All registered taxpaying establishments must send every year to the Ministry of Labor information about every single worker who had been employed by the establishment anytime during the reference year. The RAIS information provides a matched employeremployee longitudinal data set, similar to those available in developed countries, covering the formal labor market. The novelty differential of these data is to combine the matched employer-employee structure with detailed information available on workers' occupation. The full data base is too large (about 25 million workers per year), with related computational difficulties. So we use samples. Those information allow us calculate at firm level wages, age, tenure and schooling.

PIA and RAIS are connectable through a common firm identification number. And workers have a permanent social identification number (PIS). We match 1998 to 2005 editions, get a $10 \%$ workers random sample in the manufacturing sector and build a larger unbalanced panel with workers respectively personal and firm information. Table 1 below gives details about our total and in each year worker sample.

Table 1 - Industrial Workers Sample Details

\begin{tabular}{cccccccccc}
\hline YEAR & $\mathbf{1 9 9 8}$ & $\mathbf{1 9 9 9}$ & $\mathbf{2 0 0 0}$ & $\mathbf{2 0 0 1}$ & $\mathbf{2 0 0 2}$ & $\mathbf{2 0 0 3}$ & $\mathbf{2 0 0 4}$ & $\mathbf{2 0 0 5}$ & TOTAL \\
$\mathrm{N}^{\mathrm{o}} \mathrm{obs}$ & 230.133 & 241.006 & 251.708 & 241.553 & 274.628 & 277.664 & 321.413 & 322.510 & 2.160 .615 \\
\hline
\end{tabular}

\section{Results and Interpretations}

We start with descriptive statistics - which are fundamental to characterize the database used, including information related to more than 2 million workers and more than 18.000 firms between 1998 and 2005. Next, we present the results for the regressions

\footnotetext{
${ }^{8}$ This 4-digit follows CNAE classification, which follows international standards. We must use the most desegregated level as possible (in this data base it is 4-digit). On the contrary we could wrong calculate market share. See Sutton (1998).
} 
detailed in the above section, and we finish by comparing the results obtained here with evidence for other countries.

TABLES 2 and 3 inform the central tendency measures and dispersion for continuous variables used for the analysis, as well number of observations. Wage (W) average is 6.89 minimum wages $(\mathrm{MW})^{9}$ and the median is $3.74 \mathrm{MW}$, with standard deviation of 10.07 MW. According to the percentiles, 5\% of workers earn less than $1.3 \mathrm{MW}, 75 \%$ earn less than 7.37 MW and 5\% earn more than 23.07 MW. That is, there is significant wage dispersion - confirming the well documented wage inequality and revealing polarization of earnings in Brazil - and most workers earn less than $4 \mathrm{MW}$.

The educational levels used here are low (illiterate, incomplete 4th grade, complete 4th grade and incomplete 8 th grade), intermediate (complete 8 th grade, incomplete and complete high school education), and high (incomplete and complete college education). We choose compact education levels in those three classes because, according to Brazilian Ministry of Education, it is very difficult a Brazilian, specially working, change from one level to another. Effectively, a Brazilian worker has low probability to change from low education level to intermediate, and from intermediate to high. To compensate this traditional educational mobility rigidity, SENAI offers continuous technical training to Brazilian industrial workers in technical schools in the whole country. Education changes over time, indeed.

Mean educational level (SCHOOL) corresponds to 1.78 while median educational level is 2 , on a scale that ranges from 1(low) to 3 (high), with a standard deviation 0.65 . Only $5 \%$ of sampled workers are at the highest level. Mean tenure (TEN) is 60.59 months, and median TEN is 33.2 months, with substantial dispersion - and a standard deviation of 70.20 months. Only 5\% of sampled workers had more than 18 years of tenure. The mean and median age is about 33 years, but $75 \%$ of sampled workers are younger than 40 years old. In sum, the descriptive statistics suggest that most formal workers in the Brazilian manufacturing industry in our sample are young, have a low educational level, have few years of tenure and earn less than 4 MW. Mean market share (MS, ratio between the revenue of firm $\mathrm{j}$ and the revenue of firms in the manufacturing sector where firm $\mathrm{j}$ operates) of about 18.000 sampled firms is around $12 \%$, while median MS is $3.5 \%$, with a standard deviation of $18 \%$. Seventy-five percent of the sampled firms have a market share lower than $14 \%$, and 5\% have an MS greater than 52\%, i.e.

\footnotetext{
${ }^{9}$ As descriptive statistics show, most of workers income is below 4 minimum wages (MW), almost $75 \%$ of wages are below $7 \mathrm{MW}$, close to $20 \%$ of wages are between 7 and $23 \mathrm{MW}$, and close to $5 \%$ are above $23 \mathrm{MW}$. We should use a price index as deflator according to each group income, i.e., at least 3 different deflator. It brings too much noise to regression, as each price index has a specific methodology. So, MW is the best option as deflator, as it at least doesn't bring noise to regression. At least, Ministry of Labor official statistics reports wages series in MW because of it.
} 
in general, market share is low, with a high concentration restricted to a small group of sampled firms.

Table 2 - Descriptive Statistics for Continuous Variables

\begin{tabular}{lccc}
\hline Variable & Observations & Mean & Std deviation \\
W & 2.160 .615 & 6.89 & 10.07 \\
SCHOOL & 2.160 .615 & 1.78 & 0.65 \\
TEN & 2.160 .615 & 60.59 & 70.20 \\
AGE & 2.160 .615 & 32.91 & 9.51 \\
MS & 18.560 & 0.12 & 0.18 \\
\hline
\end{tabular}

Soure: Based on data from RAIS and PIA.

Table 3 - Percentiles of Continuous Variables

\begin{tabular}{lccccc}
\hline Variable & P5 & P25 & P50 & P75 & P95 \\
W & 1.3 & 2.24 & 3.74 & 7.37 & 23.07 \\
SCHOOL & 1 & 1 & 2 & 2 & 3 \\
TEN & 2.3 & 11.5 & 33.2 & 82.5 & 214.4 \\
AGE & 20 & 25 & 32 & 39 & 50 \\
MS & 0.0009 & 0.008 & 0.035 & 0.14 & 0.52 \\
\hline
\end{tabular}

Source: Based on data from RAIS and PIA.

To deal with causality, we follow an important applied econometrics literature and choose to include a quasi-natural experiment in the analysis - in this case, the exchange rate overshooting for 2002 to 2003 - in order to rule out potential endogeneity. According to Graph 1, the Real/U.S. dollar exchange rate between 2002 and 2003 changed substantially - a fact that was attributed to electoral expectations in that period. Between January and May 2002, the R \$/US\$ exchange rate had a mean daily rate between R \$2.3 and R \$2.5. In June 2002, it rose to R \$2.8; between July and August, it amounted to $\mathrm{R} \$ 3.0$, and in September, to $\mathrm{R} \$ 3.9$. From October 2002 onwards, the exchange rates started to go in the opposite direction. Between October and November 2002, the US currency could be bought for R\$3.60. Between December 2002 and March 2003, the rate was around $\mathrm{R} \$ 3.5$; and between April and December 2003, it oscillated between R \$2.8 and R \$3.0. In brief, the R\$/US\$ rate for September 2002 was around $70 \%$ higher than that for January 2002; and the rate for April 2003 was around 20\% smaller than that for September 2002. The exchange rate fluctuation between 2002 and 2003 has been attributed solely to political risk, as an untested left wing candidate was posed to win the election (Luiz Inácio Lula da Silva). ${ }^{10}$ After it assured the nation that

10 Real devaluation as electoral expectation was a surprise because: 1) Lula has had run and lost 3 presidential elections and 2) donation is a good proxy to market expectation. According to Brazilian Electoral Court (TSE), Lula's Party (PT) won R\$ 21 million in donations, while Jose Serra party (PSDB) won R\$ 34 million in 2002 election, or $65 \%$ more than Lula's party. It means that market expected Serra victory and Lula won 2002 presidential election was a great surprise. 
the inflation targeting policy would continue and it actually raised the primary surplus in its first days in office, the exchange rate consolidated a descent.

\section{Figure 1 - R\$/US\$ exchange rate}

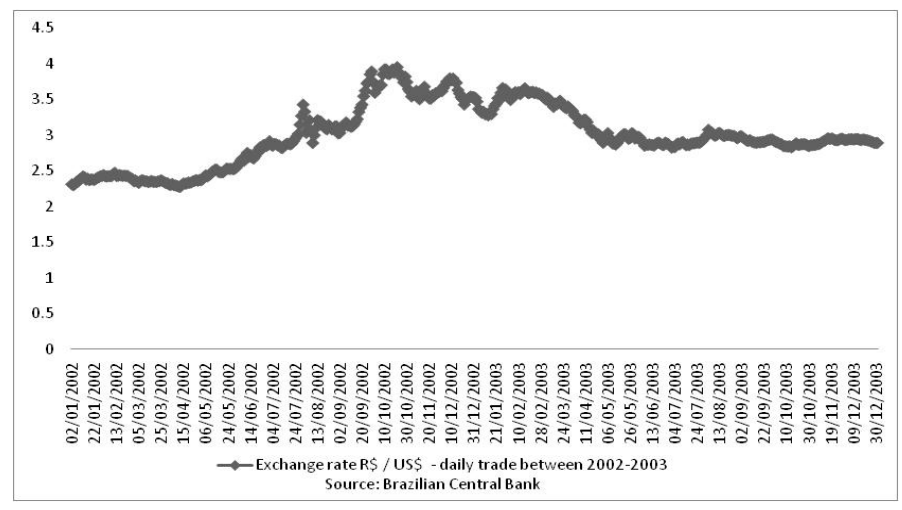

This can regarded as an exogenous shock. The definition of two periods - before and after the experiment, captured by the dummy for 2002, makes the ordinary least squares estimates equivalent to the difference-in-difference estimates of wage differentials, considering observable qualification indicators, especially educational level. Table 4 sums up our specification, which includes quasi-natural experiments (exchange rate overshooting) as alternative solution to potential endogeneity, has the aim to capture the effect of market share on wages, considering the qualification of workers in the Brazilian manufacturing industry, avoid potential endogeneity. We see the majority of coefficients are significant but some of them very small, as tenure and age. Among skills proxies, school level has the strongest impact on wages. Market structure (MS) has negative impact on wages, but this effect change if conditional to schooling. MS effect in high school level also is bigger than in medium - in fact, far bigger. Exchange rate overshooting in 2002 effect on wage is negative on average, but it is not significative for medium school level and it is positive to high. Market share interaction is also not significant (MS*D02), but it has positive effect if we consider school levels (MS*D02*DM, MS*D02*DH). We could say that workers with higher skills receive much higher wages than unskilled workers, as expected, and this differential increases with firm market share. Should we interpret market share as market power, firms with more market power pay higher wages for skilled workers and relatively lower wages for unskilled workers.The economic channel through which the Real devaluation handles the endogeneity problem is quite simple but not obvious. In 2002, the Real experienced devaluation. This can be seen as an exogenous shock that affected industries differently depending upon their openness to trade. The depreciation affected more deeply 
industries that were relatively open before 2002. Its direct effect was to increase the prices that foreign competitors could offer in the Brazilian market and to decrease the number of potential foreign competitors who could sell in Brazil. Put differently, it increased the costs of foreign relative to Brazilian firms, which increased equilibrium prices proportionally to the extent of the increase in competition.

Table 4 - Skills, 2002 Overshooting and Market Share

\begin{tabular}{|c|c|}
\hline \multicolumn{2}{|l|}{ Lnw } \\
\hline CONSTANT & $5.56(0.07)^{* * *}$ \\
\hline TEN & $0.005(0.000178)^{* * *}$ \\
\hline AGE & $-0.006(0.002)^{* * *}$ \\
\hline DMS & $0.94(0.034)^{* * *}$ \\
\hline DHS & $5.84(0.06)^{* * *}$ \\
\hline D02 & $-0.15(0.034)^{* * *}$ \\
\hline D02*DMS & $0.013(0.045)$ \\
\hline D02*DHS & $0.32(0.07)^{* * *}$ \\
\hline MS & $-1.47(0.21)^{* * *}$ \\
\hline MS*D02 & $-0.19(0.23)$ \\
\hline MS*DMS & $0.53(0.17)^{* * *}$ \\
\hline MS*DHS & $4.51(0.20)^{* * *}$ \\
\hline MS*D02*DMS & $-0.03(0.25)$ \\
\hline MS*D02*DHS & $1.48(0.28)^{* * *}$ \\
\hline FFE & Yes \\
\hline WFE & Yes \\
\hline FFE*WFE & Yes \\
\hline $\mathrm{R}^{2}$ total & 0.25 \\
\hline $\mathrm{R}^{2}$ within & 0.05 \\
\hline $\mathrm{R}^{2}$ between & 0.25 \\
\hline \multicolumn{2}{|l|}{ Test $\mathrm{F}$ for } \\
\hline All variables & $\mathrm{F}(13,593.954)=2368.82 * * *$ \\
\hline MS*D02, MS*D02*DMS, MS*D02*DHS, D02*DMS,D02*DHS & $\mathrm{F}(5,593.954)=54.46 * * *$ \\
\hline MS*D02,MS*D02*DMS, MS*D02*DHS & $\mathrm{F}(3,593.954)=24.61 * * *$ \\
\hline D02*DMS,D02*DHS & $\mathrm{F}(2,593.954)=11.76^{* * *}$ \\
\hline MS*DMS,MS*DHS & $\mathrm{F}(2,593.954)=447.84 * * *$ \\
\hline Observações & 2.157 .741 \\
\hline
\end{tabular}

Source: Our own tabulation from Rais and PIA (1998 to 2005).

$* * *, * *,{ }^{*}$ means significance at $1 \%, 5 \%$ and $10 \%$, respectively.

Cluster robust standard errors between parentheses.

lnw is worker $\mathrm{i}$ with schooling $\mathrm{k}$ at firm $\mathrm{j}$ in year $\mathrm{t} \ln$ wage; TEN is worker $\mathrm{i}$ tenure at firm $\mathrm{j}$; AGE is worker $\mathrm{i}$ age in year t, DMS and DHS are medium and high schooling levels of worker $\mathrm{i}$ in the year t; D02 is 2002 dummy; D02*DMS and D02*DHS are year and schooling dummy interactions; MS*DMS and MS*DHS are MS and schooling dummies interactions; and MS*D02, MS*D02*DMS, MS*D02*DHS are market share and year and schooling dummies interactions.

By comparing the results obtained here for Brazil with the evidence shown in the international literature, we noted that, regard to the U.S. case, the literature shows that the integration of product market may increase heterogeneity because opportunities are not uniformly distributed across groups (Andersen, 2005); and that between 1990 and 2000 
there was polarization of the U.S. labor market between high - and low- wage workers, with a significant reduction in the participation of average-wage workers (Autor, Levy and Murnane, 2006). These results are also observed in Brazil, given the sign and significance of parameters for workers in each educational level. As a rule, the positive effects of exchange rate, foreign competition and market share are concentrated in workers with a high educational level, being a possible additional source of inequality. Other pieces of evidence for the United States (Brown and Medoff, 1989) and for Australia (Waddoups, 2007) suggest a positive effect of firm size on wages. In Brazil, the positive effect of firm size (measured by market share) on wages is concentrated in workers with a high educational level. For the United Kingdom, it was detected that the exchange rate fluctuation increases the returns to skill both for workers with intermediate and high qualification (Guadalupe, 2007). In Brazil, exchange rate has a positive effect only for workers with a higher qualification.

\section{Concluding Comments}

This paper estimates the impact of market structure on wages in the Brazilian industrial firms using a linked employer-employee dataset for 1998-2005. We control potential endogeneity problem through a quasi-natural experiment. Our main results are: 1) higher-skilled workers earns high; 2) the skill premium is accentuated by market share and 3) after 2002 currency devaluation, the skill premium is even higher in firms with larger market share.

Considering that the market share is also a way to measure firm size, this result also suggests that the biggest Brazilian manufacturing firms pay highly skilled workers better wages than do smaller firms. The results, to the best of our knowledge are new to Brazilian industry and some of the few in the literature at firm and worker level. From the standpoint of public policy formulation, the results obtained here indicate that it is fundamental to consider the effects of exchange rate fluctuation and market share impacts on wages in the Brazilian industrial firms, since positive effects are concentrated in workers with higher qualification. The effects of formal education and firm size on wage determination are quite important as well.

\section{References}

Abowd, J.M., Kramarz, F. (1999b), Analysis of Linked Employer-Employee Data. Labour Economics, v. 6, n. 1, p.53-74, mar. Abowd, J.M., Kramarz, F. (1999a), The analysis of labour markets using matched employer-employee data. In: Ashenfelter, O. e Card, D. (editors) Handbook of Labor Economics, volume 3B, p. 2629-2710.

Abowd, J.M.; Kramarz, F., Margolis, D.N. (1999), High Wage Workers and High Wage Firms, Econometrica, v.67, n. 2, p. 251-333, fev. 
Alatas, V., Cameron, L.A. (2008), The impact of minimum wages on employment in a low-income country: a quasinatural experiment in Indonesia. Industrial and Labor Relations Review, vol.61, n2, p. 201-223, abr.

Andersen, T.M. (2005), Product market integration, wage dispersion and unemployment, Labour Economics, v.12, n.3, p.379-406, jun.

Angrist, J.D., Krueger, A.B. (2001), Instrumental Variables and the Search for Identification: From Supply and Demand to Natural Experiments. The Journal of Economic Perspectives, v. 15, n. 4, p. 69-85, Outono.

Angrist, J.D., Pischke, J. (2009), Mostly Harmless Econometrics: An Empiricist's Companion. Boston: MIT press.

Autor, D.H., Levy, F., Murnane, R. J. (2006), The Polarization of the U.S. Labor Market. The American Economic Review. Papers and Proceedings, p. 189-194, maio. Special Issue on Measuring and Interpreting Trends in Economic Inequality.

Bertrand, M., Duflo, E., Mullainathan, S. (2004), How Much Should We Trust Differences-in-Differences Estimates? The Quarterly Journal of Economics, v. 119, n.1, p. 249-275, feb.

Besley, T., Case, A. (2000), Unnatural Experiments? Estimating the incidence of endogenous policies. The Economic Journal, v.110, n.467, p. F672-F694, nov.

Brown, C. and Medoff, J. (1989), The Employer Size-Wage Effect. The Journal of Political Economy, v. 97, n.5, p. 1027-1059, out.

Buse, A. (1992), The Bias of Instrumental Variable Estimators. Econometrica, v.60, n.1, p. 173-180, jan.

Bound, J., Jaeger, D.A., Baker, R.M. (1995), Problems with Instrumental Variables Estimation When the Correlation Between the Instruments and the Endogenous Explanatory Variable is Weak. Journal of the American Statistical Association, v. 90, n. 430, p. 443-450, jun.

Cameron, A.C., Trivedi, P.K. (2005), Microeconometrics: methods and applications. Cambridge: Cambridge University Press.

Caves, R.E., Porter, M.E. (1978), Market Structure, oligopoly, and stability of market shares. The Journal of Industrial Economics, v. 26, n. 4, p. 289-331, jun.

Durlauf, S.N., Blume, L. E. (2010), Microeconometrics. The New Palgrave Dictionary. Macmillan.

Guadalupe, M. (2007), Product Market Competition, Returns to Skill, and Wage Inequality. Journal of Labor Economics, v. 25, n. 3, p. 439-474, jul.

Haltiwanger, D. et alli. (1998), International symposium on linked employer-employee data. Monthly Labor Review, p. 48-60. Conference Report.

Lima, M. A. M., Resende, M. (2003), Profit Margins and Business Cycles in the Brazilian Industry: a Panel Data Study. XXXV Encontro Brasileiro de Econometria, Anais, Salvador.

Long, J.E., Link, A. N. (1983), The Impact of Market Structure on Wages, Fringe Benefits, and Turnover. Industrial and Labor Relations Review, v. 36, n. 2 p. 239-250, jan.

Martins, P. S., Esteves, L. A. (2006), Rent-sharing nas indústrias brasileiras. In: de Negri, J. A.; de Negri, F., Coelho, D. Tecnologia, exportação e emprego. Brasília: Ipea. p. 341-365.

Menezes-Filho, N. A., Muendler, M., Ramey, G. (2008), The structure of worker compensation in Brazil with a comparison to France and the United States. Review of Economics and Statistics, v. 90, n.2, p. 324-346, mai.

Meyer, B.D. (1995), Natural and Quasi-Experiments in Economics. Journal of Business and Economic Statistics, v. 13, n. 2, p. 151-161, abr.

Nickel, S. (1999), Product Markets and Labor Markets. Labor Economics, v. 6, n1, p. 1-20, mar.

Pesquisa Industrial Anual. PIA. 1998 to 2005 editions.

Relação Anual de Informações Sociais. RAIS. 1998 to 2005 editions.

Rosenzweig, M.R., Wolpin, K.I. (2000), Natural "Natural Experiments” in Economics. Journal of Economic Literature, v.38, n. 4, p. $827-874$, dez.

Schmalensee, R. (1989), Inter-industry studies of structure and performance. In: Schmalensee, R.; Willig, R. D. Handbook of Industrial Organization. Amsterdam: Elsevier. p. 951-1009.

Sutton, J. (1998), Market structure and technology: theory and history. Boston: MIT press.

Waddoup, J. C. (2007), Employer size-wage effects in Australia. Labour, v. 21, n. 4/5, p. 809-835, dez. 